\title{
The Manipulative Power of Word-formation Devices in Margaret Atwood's Oryx and Crake
}

\author{
Paula López Rúa \\ University of the Balearic Islands \\ paula.Irua@uib.es
}

\begin{abstract}
Apart from speculating about a series of issues open to debate, such as the dark side of progress and globalization or the conflict between science and morality, Margaret Atwood's Oryx and Crake (2003) offers a feasible insight into the state of the English language in the near future as far as the development of the lexicon is concerned. In the light of Foucault's theories on power, knowledge and discourse, this article approaches the novel from a linguistic perspective and undertakes an analysis of lexical innovation which comprises fields of interest, devices, motivations and users. The conclusions drawn from the analysis can be summarized as follows: in the first place, it is verified that the major fields of development for lexical creativity are science and technology, learning, consumerism, and media and entertainment, in other words, the fields through which number people (the group in control) exert power; secondly, from a strictly linguistic point of view, new vocabulary arises from the use of existing bases and productive word-formation devices like derivation, shortening and compounding; thirdly, the motivations behind the use of these mechanisms are critical, pragmatic, communicative and connotative, but new words are also created to ensure the perpetuation of the system; lastly, inasmuch as they form part of discourse, new items also contribute to the creation of individual and collective identities.
\end{abstract}

\section{Introduction}

Oryx and Crake (2003), the latest novel by the Canadian writer Margaret Atwood, puts forward a grim vision of the future through the eyes of Snowman, formerly Jimmy, one of 
the few human survivors of a pandemic created in a laboratory. He tries to understand the chaos which has come upon the world he knows by means of a double journey: on the one hand, there is a mental journey of scattered memories which go back to Jimmy's childhood and whose protagonists are his best friend Crake (Glenn) and his beloved Oryx; on the other hand, there is also a physical journey which leads him far from the Crakers - Crake's improved race of humans, now under Snowman's guidance and protection - and back to Crake's home and workplace (the origin of the nightmare), only to end up returning to the Crakers and to his role of interpreter of deified Oryx's and Crake's wishes.

This article approaches Oryx and Crake from a linguistic perspective. Therefore, keeping in mind the status of words as bridges between reality and thought, I carry out an analysis of how language (or discourse) is used by the privileged group (scientists) to build reality and to ensure the permanence of the status quo. In that respect, it must be noted that many aspects of the world depicted in the novel can be interpreted in the light of the theories developed by the French thinker Michel Foucault (1926-1984); in fact, some of his works, such as The Order of Things (1966), Discipline and Punish (1975) or the first volume of The History of Sexuality, The Will to Know (1976), ${ }^{1}$ provide valuable clues to decode the complex system of power relationships which is portrayed in Oryx and Crake. It must be clarified, however, that in spite of the unquestionable interest that a philosophical analysis of the novel might arouse, this article was not conceived as a philosophical but as a lexical reflection. Therefore, the allusions to Foucault's writings have been limited to those remarks and quotations which might help to understand lexical creativity in Atwood's work.

Discourse, power and knowledge are the three apices of Foucault's philosophical universe, and they form a vicious circle in the novel. In a world where inequality and segregation arise at all levels, "number" people (scientific minds) are the group in power, whereas "word" people are marginalized. The latter are associated with the underrated humanities, which include literature and the arts. The loss of prestige of humanities which is shown in the novel could be interpreted as being in agreement with the precarious status that Foucault ascribes to social sciences (psychology, sociology and the study of literatures and myths) within the epistemological trihedron in The Order of Things:

Quizá es esta repartición nebulosa en un espacio de tres dimensiones lo que hace que las ciencias humanas sean tan difíciles de situar, lo que da su irreductible precariedad a su localización en el dominio epistemológico (...) Si el hombre no es ya soberano en el reino del mundo, (...) las "ciencias humanas" son intermediarios peligrosos en el espacio del saber. (...) esta postura misma las entrega a una inestabilidad esencial. Lo que explica la dificultad de las "ciencias humanas", su precariedad, su incertidumbre como ciencias, su peligrosa familiaridad con la filosofía, su mal definido apoyo en otros dominios del saber, su carácter siempre secundario y derivado (...). (Foucault, 1968: 337-338)

In accordance with Foucault's tenets, power is exerted and maintained through the production of knowledge (scientific knowledge) and the production of discourse. The latter is taken as universal truth because it is actually produced by the group in power. In 
Power/Knowledge (1980: 133), Foucault explains the relationship between truth and power as follows: "Truth is linked in a circular relation with systems of power which produce and sustain it, and to effects of power which it induces and which extend it." Furthermore, power is maintained because it "traverses and produces things, it induces pleasure, forms knowledge, produces discourse" (1980: 119). As already noted, another important aspect of the connection between power, truth and discourse is that those in power have specialist knowledge, and this is what happens to number people in the novel: in Foucault's words, "truth is centred on the form of scientific discourse and the institutions which produce it (...) it is produced and transmitted under the control of a few great political and economic apparatuses (university, army, writing, media)" (1980: 131-132). Having specialist knowledge provides power and control because the specialist's word is regarded as authoritative, hence the power.

Lastly, it must also be noted that, in order to exert power, the futuristic élite of scientific minds preserves the view of population as workforce and as a measure of wealth (a notion which dates back to the Industrial Revolution); this view implies a careful consideration of all the variables concerning population, such as longevity, housing and food, health, and sex (which includes fertility, birth control and sexual practices), since it is by controlling the variables that the population can actually be controlled. The necessary attention paid by governments to these elements is commented on by Foucault when describing the repressive hypothesis in The History of Sexuality, and it could explain why quite a few new lexical items in the novel are actually related to youth, health and beauty, food, and sex (see Section 2 below).

The paragraphs above summarize how some philosophical principles sustained by Foucault are actually reflected in the world of the novel. On these grounds, and since the focus of this study is on lexical innovation within discourse, the body of the article has been divided into sections devoted to the description of the fields of interest for lexical creativity, the devices resorted to, the possible motivations behind the choice of those devices, and also the speakers' perspective, that is, the collective and individual uses of lexical innovation. This account includes occasional references to a classic futuristic novel where the links between language, reality and thought are similarly explored: George Orwell's Nineteen Eighty-Four (1949).

\section{Fields}

Despite the lack of concrete time references, the novel appears to be set in Canada in the near future; in fact, a few references are made to specific Canadian locations, such as Hudson's Bay or Montreal. It is possible to infer that the events described could be taking place in around fifty years' time from now. The world is starting to suffer the consequences of global warming. Mankind lives under the threat of viruses which can spread worldwide in record time and coldly watches localized armed conflicts from a computer screen. The Internet is the basic means of communication and entertainment. Science and morality clash 
in genetic experiments, and powerful multinationals turn consumerism into slavery. In a word, it is a world ruled by science, corruption, inequality, selfishness, consumerism, violence and insecurity, and the novel's open ending does not seem to suggest a promising future for the small number of human survivors.

Although all spheres of life are likely to be affected by the changes brought about by the new times, this is not actually reflected in the text since the novel offers a view of reality which is limited by the characters' perspective and interests. The focus here is on science, learning and consumerism, which are the areas where the group in power exert their influence. The changes in people's way of life which are shown in the novel basically affect working conditions, housing, education, leisure, and scientific and technical development, so those are areas of growth for new vocabulary. The most important fields of development for lexical creativity are therefore brand names, scientific and technical inventions, school and university subjects and, to a lesser extent, place names and media and entertainment. In accordance with Foucault's views, scientists (the group in power) create a discourse which suggests the existence of a convenient system of values which must be preserved. Therefore, discourse (and new lexical items within discourse) make youth, health, beauty, sexual pleasure, birth control and scientific and technological advances appear as highly desirable. This truth is blindly accepted by the public, whose demands are satisfied by scientists by means of inventions. In this way scientists are apparently giving people what they freely choose, but in fact they are only giving them what they themselves consider necessary to stay in power. Accordingly, they will come up with pills to enhance sexual potency, viruses to make people buy antidotes, numberless products to preserve youth and beauty, genetic alterations to obtain perfect babies, and even hybrid pets for entertainment.

\subsection{Brand names and inventions}

The preliminary analysis of new vocabulary shows that the richest fields for lexical creativity are brand names (Happicuppa coffee, SoYummie ice cream, Happicuppuchino, SoyOBoy burgers, ChickieNobs, Fountain of Yooth Total Plunge - an exfoliant treatment) and scientific and technical inventions like hybrid pets, toys and medicaments. Science and consumerism are naturally linked in the novel so that the privileged group can stay in power: as already mentioned, scientific inventions are massively consumed because they comply with the public's demands for health, youth and life quality. In a world where scientific research has been corrupted by commercial interests, consumers find themselves at the mercy of professional 'persuaders' like Jimmy (whose work for the corporation AnooYoo consists in describing the products they manufacture so as to make them sell good). Under the belief that scientists actually work to improve the quality of life, the public is easily deceived with promises of eternal youth, unlimited sexual potency or irresistible personality, and becomes an easy target for the unscrupulous multinationals which work hand in hand with scientists to maintain the status quo.

Scientific and technological advances have particularly taken place within the field of 
genetic engineering. Scientists revel in their godlike power to create by experimenting with all kinds of life-forms: animals, plants and even human beings. Thus parents are encouraged to choose their babies' features in specialized agencies, which provide race improvement on a small scale. Jimmy dispassionately talks about that possibility for his father and step-mother as if it was an everyday occurrence:

They'd try "something else" from one of the agencies - Infantade, Foetility, Perfectababe (...). Terrific, thought Jimmy. They'd have a few trial runs, and if the kids from those didn't measure up they' $d$ recycle them for the parts, until at last they got something that fit all their specs - perfect in every way, not only a math whiz but beautiful as the dawn (Atwood, 2003: $250)^{2}$

Animals are genetically altered while preserving some of their original features, and that process is parallelled in their names: for example, pigoons are genetically altered pigs, and bobkittens (smaller and supposedly harmless) have been artificially developed from bobcats. Similarly, animal hybrids are conveniently denominated using blends: for instance, rakunks are popular pets combining the best features of racoons and skunks, whereas snats (hybrids of snakes and rats) and wolvogs (hybrids of wolves and dogs) are the dangerous result of experiments which got out of the scientists' control. In a world where science is exalted as all-powerful, this failures can be interpreted as warning signs of human limitations.

The "Children of Crake" are the latest step in the race towards improvement. Childishly naïve and easy to control, these pseudo-human creatures exhibit physical and behavioural features of different animals which were carefully selected by their creator in an attempt to liberate mankind from the hardships of illness, ageing, love and abstract thought. Insensitive, unimaginative and flawless, the Crakers have actually been divested of everything that makes up a human being. However, their darkest side is not their inhuman quality, but the fact that they are part of Crake's scheme to place himself at the apex of power as the only ruler in a totalitarian system.

\subsection{School and university subjects}

The changes in the way of life brought about by scientific and technological advances find a natural reflection in new school and university subjects. New learning needs arise in a science-ridden world which must face environmental problems, food shortage and the permanent threat of biological warfare. For example, during his school years Jimmy learns Geolonomics, Nanotech Biochem and Life Skills:

The Life Skills class, in junior high (...). Double-entry on-screen bookkeeping, banking by fingertip, using a microwave without nuking your egg, filling out housing applications for this or that compound, family heredity research, negotiating your own marriage-and-divorce contracts, wise genetic match-mating, the proper use of condoms to avoid sexually transmitted bioforms: those thad been the Life Skills (OC: 46-47). 
At university, science degrees adjust to the advances in different fields through subjects like Neo Agriculturals, Neo-Geologicals or BioDefences. Although considerably devalued due to their uselessness for the privileged group's interests, the humanities also try to keep up with the times by offering degrees like Problematics or Pictorial and Plastic Arts, and subjects such as Webgame Dynamics or Applied Rhetoric:

Depending on how well he did in his Problematic courses - Applied Logic, Applied Rhetoric, Medical Ethics and Terminology, Applied Semantics, Relativistics and Advanced Mischaracterization, Comparative Cultural Psychology and the rest - he'd have a choice between well-paid window dressing for a big Corp or flimsy cut-rate stuff for a borderline one (OC: 188).

\subsection{Place names}

Oryx and Crake starts from the premise that, in a world dominated by science, number people like Crake (that is, scientific minds) naturally enjoy educational and working privileges and society's general appreciation because they are perceived as useful: they can make life improve with their discoveries and satisfy the public's needs. On the contrary, word people like Jimmy, who represents the world of the arts, are tolerated but undervalued because, in the public's view, they can do nothing to satisfy their demands for health, beauty, youth and the rest of desirable values set up by the group in power.

The population in the novel is basically divided into pleebland inhabitants and compounders. This division highlights social inequalities and reflects the atmosphere of insecurity in which people live. A minority of privileged families whose members work for scientific corporations (mainly science people) lives in compounds, protected areas with their own facilities which receive the same names as the corporations, thus reinforcing the feeling of exclusivity. For example, Jimmy remembers that when he was a child his father worked for the OrganInc Farms, devoted to rearing pigoons for mass production of organs destined to human transplants; therefore, the family lived in the OrganInc Compound and Jimmy attended the OrganInc School. Further examples of compounds similarly linked to enterprises are HelthWyzer (which applies to the firm, the compound, the gate, the public school and the dental clinic), RejoovenEsence, CryoJeenyus or AnooYoo. Their method of formation and other features will be duly discussed in Section 3. In agreement with Foucault's hypothesis about how power operates thanks to disciplinary domains, the group holding power applies the principles of isolation, surveillance and visibility in order to control the population: as Foucault thoroughly describes in Discipline and Punish (1995: 195 and following), these principles are at work in Bentham's panopticon, a disciplinary building whose major effect is to induce a state of conscient and permanent visibility that ensures the automatic functioning of power. The panopticon is a circular building with individual cells and a tower at the centre from which a supervisor can observe the captives without being watched. In Oryx and Crake, compounds are redoubts of class privilege, but they also keep their inhabitants under permanent control and isolate them from what they 
believe to be a threatening world. Individualization and the development of a sense of being permanently watched are also guiding principles for the group in power in Nineteen Eighty-Four, another illustration of Foucault's disciplinary society.

In contrast with the minority of compounders, most of the population lives in the cities or pleeblands, a word in which it is possible to spot the pejorative component pleb or plebs. The pleeblands are dangerous territories, unhealthy, overpopulated and, on the whole, quite similar to the slums (the "proletarian quarters") where the proles in Nineteen EightyFour live. Following the controlling principles mentioned above, compounders are strongly advised against entering the cities alone:

There was always a risk when you went through the city (...). Compound people didn't go to the cities unless they had to, and then never alone. They called the cities the pleeblands (...), public security in the pleeblands was leaky: there were people who could forge anything and who might be anybody, not to mention the loose change - the addicts, the muggers, the paupers, the crazies $(O C: 31)$.

She'd booked a CorpSeCorps man as a protection in the taxi-ride from the sealed bullet-train station through the short stretch of pleebland that had to be crossed (...), which was the usual thing to do (OC: 62).

Nevertheless, it must be noted that in both novels these realms of poverty, crime and insecurity are rather appealing to 'outsiders' because there they can feel free or be themselves. In Nineteen Eighty-Four, Winston and Julia's temporary love nest is a rented room in the poor quarters; along the same line, Crake and Jimmy's nocturnal incursion into the dangerous city is regarded by both as an exciting event and devoted a chapter humorously entitled pleebcrawl, a denomination apparently patterned after pubcrawl.

\subsection{Media and entertainment}

Finally, mass media and entertainment are also fields for new vocabulary. Computers have become the windows on the world and, since the written word relates to the despised discipline of literature, books have almost been replaced by CD-ROMs. Moreover, the Internet has superseded TV as the primary means of communication and entertainment. Teenagers Crake and Jimmy's favourite pastime is to surf the net in search of interesting websites, and they are able to watch a reality show, an execution or sexual abuse with the same indifference and childish amusement. There are a few references to sites showing various types of live programmes, for instance hedsoff.com, which shows live executions, HottTotts, a site of child pornography, or Noodie News, a programme where presenters strip while broadcasting the news. Some more examples are gathered in the quotation below:

They'd watch animal snuff sites, Felicia's Frog Squash and the like, though these quickly grew repetitious: one stomped frog, one cat being torn apart by hand, was much like another (...). 
Or they could watch alibooboo.com with various supposed thieves having their hands cut off and adulterers and lipstick wearers being stoned to death (...). Shorcircuit.com, brainfizz.com, and deathrowlive.com were the best; they showed electrocutions and lethal injections (OC: 82-83).

Like the endless war in Nineteen Eighty-Four, conflicts and violence are necessary and beneficial for the group in power: watching distant conflicts diverts people's attention from their actual problems and creates a sense of grateful well-being which results from comparing their situation with what is happening somewhere else.

Sexuality is another advantageous strategy used by the privileged group to stay in power; as Foucault observes in The History of Sexuality, "pleasure and power do not cancel or turn back against one another; they seek out, overlap, and reinforce one another" (1978: 48). The privileged group is aware that the practice or observation of anomalous sexual conducts (including child pornography) is appealing to a sector of society which must also be controlled, in this case through stimulation and satisfaction. This line of conduct agrees with Foucault's suggestion (put forward in Power/Knowledge) that power responds to the revolt of the body in modern times by exerting control not through repression but through stimulation. Therefore, it encourages the search for beauty, youth and pleasure (all of them desirable values in the society of the novel), and carries out "an economic (and perhaps also ideological) exploitation of eroticisation, from sun-tan products to pornographic films" (1980: 57). In Oryx and Crake sexual perversions are efficiently exploited and regulated by the group in power so as to keep control. The value of perverted sexual practices is noted by Foucault in The History of Sexuality when he remarks that "the implantation of perversions is an instrument-effect: it is throught the isolation, intensification and consolidation of peripheral sexualities that the relations of power to sex and pleasure branced out and multiplied, measured the body, and penetrated modes of conduct" (1978: 48 ). In order to be an instrument of power, sex should not be "simply condemned or tolerated but managed, inserted into systerns of utility" (1978: 24); that is why the group in control punishes but at the same time permits those activities (since they are illegal but accessible via the Internet). Sex is also used by the group in power when they promote birth control and the physical aspect of sexual relationships as desirable aims. Scientists isolate the sensual side of sex and put it up for sale in the BlyssPluss Pill, which turns out to be Crake's means to introduce his improved race of humans. Crake is conscious that people can be controlled by the physical and the emotional aspects of sex, that is why he designs his Crakers with simple animal instincts which dissociate sex from pleasure.

Computer games are the basic form of entertainment, and their contents are also violent or pornographic in many cases. A few examples are Kwiktime Osama, Barbarian Stomp, Three-Dimensional waco or Extinctathon, a game where participants have to guess the names of extinct life-forms and from which the names Oryx and Crake are taken: both are names of animals which became extinct at the time of the novel (curiously enough, the characters named after them are also dead when Jimmy starts gathering his memories). 
As can be noticed, vice, corruption, violence and the impression that everything is for sale pervade both sites and games, but people have become accustomed to turning a blind eye to events which do not affect them directly. The lack of concern for the atrocities which are shown on the net criticizes a situation which is dangerously similar to real life. Sarcasm and hyperbole pervade both new vocabulary items and new combinations of old items, and their use can be interpreted as the implied author's tool to portray an alternative world which denounces the real one.

\section{Devices}

As will be further on explained, a realistic feature of lexical creativity in Oryx and Crake is that new vocabulary does not arise from word manufacture: in other words, and borrowing Bauer's terminology, words are not created ex nihilo, "with no morphological, phonological or orthographic motivation" (1983: 239). Instead, new items resort to already existing bases and productive word-formation devices, particularly shortening and compounding. The combination of both processes in blends and clipped compounds is actually the most productive device, together with the respelling of already existing words and phrases. It must be noted that, although respelling can not be regarded as a wordformation device, its remarkable productivity and the motivations behind its use make it worth describing in the present case.

\subsection{Derivation}

The productive use of derivational morphemes is quite restricted in the novel. The prefix neo- is added to nouns mainly referring to school and university subjects and departments (Neotechnology, Neo-Geologicals, Neo Agriculturals). There are also several isolated cases of suffixation. For example, pigoon combines the root pig and the suffix -oon ('large') which occurs in words borrowed from Romance languages (bassoon, balloon, dragoon). Moreover, following the pattern of piglet, the suffix -let is added to pigoon in order to form pigoonlet. The diminutive suffix $-y$ /-ie occurs in items like ChickieNobs ("chicken knobs'). Jimmy's former girlfriend Amanda, a conceptual artist, invents the word vulturize to refer to her art: she builds vulture sculptures using dead animals to form words and taking photographs from the air when vultures fall upon them. Another instance of derivation is the term Crakers, made up by Oryx to name the improved race of humans created by Crake.

\subsection{Compounding}

Although there are a few instances of straightforward compounding, for example, bullet train, for the most part newly created items belong to the subcategory of neoclassical compounds, which are described in Bauer (2004: 76) as "words made up of stems from the 
Classical languages, Latin and Greek", for example, biology. Constituents in these compounds are called "combining forms" and, according to Bauer, they "may be used in connection with independent words, as in (...) insecticide" (2004: 77). Since genetic experiments with different life-forms play an important role in the novel, it is not surprising to register a productive use of the combining form bio-, which occurs as the initial constituent in a number of compounds (biosuit, bioform, biolab, biotechnologies, bioterrorist, bioattack). Less frequent is the initial combining form gen-, which exhibits a similar behaviour and occurs in items like genographer (a scientist concerned with the writing of genetic maps) or genalteration.

\subsection{Shortening: clippings and initialisms}

As regards syllable-based shortenings, the use of already existing clipped forms is quite frequent in the novel, which is a reflection of the speakers' informal tone: specs (specifications), combo (combination), abs (abdominals), mike (microphone), execs (executives), Corp (Corporation) or videocams (videocameras) are just a few examples. Besides, there are a few informal abbreviations of new creation, such as Biochem(istry), neo-con(tender), Rejoov(enEsence) or Pleeb(land)s.

The reduction of items to initials is nowadays an extensively used device to create new words or at least to abbreviate existing ones, particularly in fields like computers, science or the army. Therefore it is quite remarkable that, in a world ruled by science and technology, only a few current initialisms are used, among them $A T M$ ('automated teller machine'), $T V, D V D, C D, C D-R O M$, and $A T V$ ('all-terrain vehicle'). As regards new creations, leaving aside the abbreviation PON ('Profanity, Obscenity and Nudity', which refers to the adult version of historical episodes provided in a computer game), only two new items occur. One of them is Crake's personal creation and belongs to his own vocabulary, so it is only intended for communication on a small scale: NTS stands for "neurotypicals", a pejorative term used to refer to mentally average people. The other initialism is JUVE ('Jetspeed Ultra Virus Extraordinary'), the virus responsible for the pandemic which almost drives human race to extinction at the end of the novel. As regards content, obvious paralellisms can be drawn between futurist JUVE and current AIDS or SARS ('severe acute respiratory syndrome'), although from a formal point of view JUVE is the result of a current trend in acronym creation in which the item is deliberately coined so that it shares semantic features with a previous word. The process of coinage is thus reversed, since the expanded expression lying behind the acronym is built around the constituent letters of the selected word. In the present case, juve- (a splinter of Latin origin) was probably chosen to build the initialism because the pandemic was caused by one of Crake's inventions, the BlyssPluss Pill, which promised protection against sexually transmitted diseases, birth control, an increase in sexual energy and also a prolongation of youth. The choice of the term is therefore intentionally ironic, since a product devised to extend youth eventually causes death. 


\subsection{Shortening plus compounding: blends and clipped compounds}

Together with respelling, the combination of shortening and compounding is by far the most productive word-formation device in the novel, and it is mainly used for inventions. Ironically enough, scientific geniuses seem to be in a continuous struggle to find artificial union while the world in the novel splits: human division arises at all levels, individually and collectively, which is perhaps a reflection of Canada's difficulties to build a common national identity. Thus number people keep apart from word people, Crakers are segregated from humans, compounders avoid the pleebland inhabitants, and Snowman eventually chooses to isolate himself from the group of survivors and stay with the Crakers. At an individual level, former Jimmy is constantly contrasted with current Snowman.

Blends and clipped compounds are the result of combining already existing constituents with different degrees of phonic and graphic integration (that is, from maximum fusion in pure blends to simple concatenation in clipped compounds), and shortening at least one of the bases. In prototypical clipped compounds the constituents are initial splinters joined with a low degree of phonic integration - i.e. with simple clustering - for example, Alcan: 'Alaska + Canada'. In the novel, both blends and clipped compounds are used to name animal hybrids resulting from genetic experiments, for instance wolvog (wolf + dog), snat (snake + rat), rakunk (racoon + skunk), spoat or gider (spider + goat), and kanga-lamb (kangaroo + lamb). Inventions combining features of two objects resort to the same device, for example robodog (robot + dog) or rockulator (rock + regulator: a system to regulate climate and water). Further examples are names of subjects and university degrees (Geolonomics: Geology + Economics; VizArts: 'Visual Arts'; PicPlarts: 'Pictorial and Plastic Arts'), or collectives and enterprises, like CorpSeCorps ('Corporation Security Corps'), EduCompounds ('Education(al) Compounds'), OrganInc(orporated) - popularly known as OrganOink - and Foetility (foetus + fertility, an agency providing babies created through genetic manipulation). In a few cases the resulting items are respelled so as to imitate speech, for example, the RejoovenEsence (rejuvenation + esence) compound belongs to a corporation which researches into the prevention of ageing, and in the CryoJeenyus (cryogenics + genius) compound scientists freeze people to revive them in the future. Finally, the computer game Extinctathon can be analysed either as a blend of 'extinction' and 'marathon' or, following Pyles and Algeo (1982), as a base plus a new "morpheme" - (a)thon created from blending in the same way as -holic. The attached meaning would be something along the lines of 'group activity lasting for some time and involving competition', as in showerthon, fastathon or cakethon:

Other new morphemes formed by blending are -holic (...) and -thon (...). The second is the tail end of marathon, whence the notion of endurance in such charitable affairs as a showerthon (during which students took turns showering for 360 continuous hours to raise money for the American Cancer Society), a fastathon (in which young people all fasted for 30 hours to raise money for the needy), and a cakethon (a five-hour auction of homemade cakes for the Heart Association) (1982: 280-281). ${ }^{3}$ 


\subsection{Respelling}

There is a strong tendency towards phonetic respelling with two variants. First, the respelling of isolated words, for example: Fountain of Yooth ('youth'), the Paradice ('paradise') dome (the place where Crake works), Three-Dimensional waco ('wacko'), Noodie (from 'nudie') News, or NooSkins ('new skins'), a scientific corporation. Second, the respelling of phrases, which are thus reduced so as to imitate words, for instance, HelthWyzer ('health wiser' i.e. 'wiser with respect to health'), AnooYoo ('a new you'), Happicuppa ('happy cup of') coffee, Infantade ('infant aid') and Perfectababe ('perfect a babe'), two other firms like Foetility, or BlyssPluss (the name of Crake's lethal pill, which could be rephrased as 'adding happiness').

\section{Motivations}

To begin with, it is possible to spot an outer level of motivation which is connected with the implied author and where criticism would be located. As already mentioned, new items or new combinations of old items may be loaded with irony and exaggeration so as to offer a critical view of a hypothetical near future.

Motivations for lexical creativity at an inner level, that is, those arising on the grounds of the novel's own universe, can be classified as pragmatic, communicative, connotative, and power-preserving. The pragmatic need for new words is summarized in Algeo (1991: 14) as follows: "Pragmatically, when there are new things to talk about, we need new words to name them. Or sometimes we want to talk about old things in a new way. Changes in society $(. .$.$) call for new words (...). Invention, discovery, exploration, war, commerce,$ and revolution all breed neology." In the future world depicted in Oryx and Crake some things have obviously changed, in particular as regards the fields already mentioned. New realities require new names, and that is one of the reasons behind the creation of new words.

Shortening and respelling obviously respond to the principle of the economy of language, that is, the need to save time and space in communication, but they also provide the new words with positive nuances of meaning: words created by blending or clustering originally independent constituents or by resorting to phonetic respellings acquire positive connotations of solidity, harmony and coherence (hybrids, for example, are intended to bring together the best of two individual items). The same positive impressions are intended in Nineteen Eighty-Four in items like Miniluv ('Ministry of Love'), Minipax ('Ministry of Peace') or IngSoc ('English Socialism'), where undesirable associations are avoided by means of a simultaneous process of formal and semantic shortening.

On its part, respelling brings writing closer to speech. Irregularities in spelling are perceived as decoding obstacles and therefore removed, and the items thus created (basically names of products and enterprises) gain in simplicity and reach the public more directly. Besides, respelling is convenient since written language is associated with 
literature and with the past, that is to say, with an underrated world which, according to the group in power, has nothing to offer.

Lastly, the choice of vocabulary, particularly in the names of corporations and products (happy, new, youth, health, bliss, paradise) is clearly intended to influence positive thinking with respect to the group in power. Both old and new vocabulary items are used in a discourse aimed at creating and maintaining the system of values which favours the privileged group.

\section{Users}

This section focuses on how discourse in general and lexical innovation in particular contribute to the creation of collective and individual identities.

\subsection{Collective uses of lexical creativity}

It is possible to distinguish between a collective and an individual level of use of new vocabulary. The collective level comprises both the general use of discourse made by the minority in power in order to keep that power, and a specific use where lexical creativity is intended to strengthen group bonds and keep outsiders apart, thus contributing to the reinforcement of human division in the novel. There are several instances of group specific vocabulary, particularly nicknames and in-group denominations: for example, Miss Riley, Jimmy's teacher at HelthWyzer High School, was known as Melons Riley among the students; similarly, the canteen at OrganInc Farms (Andre's Bistro) was called Grunts because of the menu, which usually included bacon, ham and pork pies.

However, the clearest examples of segregationist group vocabulary are, in the first place, the jargon used by university students at Watson-Crick (the place where Crake studies) and at the Martha Graham Academy (Jimmy's college), and secondly, what is known as "mathtalk", that is, the language of number people. One example of students" jargon is Asperger's $U$., that is, Watson-Crick, a name coined after Asperger' Syndrome which refers to the characteristics of Watson-Crick students, all of them brainy people with deficiencies in social and communicative skills. Further examples are the humorous distortion of the subject NeoAgriculturals (which is known among students as AgriCouture), the nickname Spin and Grin, which refers to Problematics (a degree for word people at Martha Graham) and especially the terms used to refer to fellow students (conspecifics) vs. outsiders (nonspecifics) at Watson-Crick: they are intended to reflect the superiority of number people in contrast with the rest of humanity. As regards mathtalk, Oryx refers to Jimmy's inferiority as a word person by saying that he does not have an "elegant mind", and Jimmy recognizes the expression as belonging to the language of number people, "the patronizing jargon that math nerds used" (OC: 166). 


\subsection{Individual uses of lexical creativity}

Finally, in this subsection I will review lexical creativity as part of the idiolects of individual characters, namely Crake and Jimmy, because their speech habits and their individual use of discourse provide valuable clues to explain their behaviour and development.

As an outstanding member of the privileged group, Crake makes up words for his scientific inventions (for example, the BlyssPluss Pill) with the features and reasons already explained. Occasionally, he also creates new terms (for example $N T$ ) which are just private jokes. While Crake's creativity is an outlet for his acid humour, Jimmy's case is far more complex. From time to time he also invents words for his job by resorting to the uncanonical use of word-formation derivational rules, for example in tensicity, fibracionous or pheromonimal. This deviating creativity is accepted and even appreciated by his superiors, since the words sound scientific and therefore convincing. They are fit for their purpose, which is to sell the products. He distorts reality with discourse so as to make it look better, in the same way as Winston reconstructs reality as part of his job for the Records Department in Nineteen Eighty-Four. Both are therefore professional manipulators of reality through words, although the discourses they produce are successfully manipulative only because they are working for the group holding power.

Apart from inventing new words, Jimmy plays with old words and their meanings: he borrows words and provides them with new meanings or rescues words which are no longer used. While still a teenager, Jimmy is fascinated with words which nobody uses any more; he tracks them, stores them up like treasures, and occasionally tries to bring them back to life. For example, he rediscovers the obsolete word bogus and uses it in his exchanges with Crake; the latter eventually adopts the word so that it becomes part of a sort of secret code for both: "'Bogus!' Jimmy yelled. It was a good word, he'd got it off an old DVD; they'd taken to using it to tear each other down for being pompous" (OC: 88). Similarly, he takes the word cork-nut (almond) from Alex the parrot (a character in a computer game) and starts using it to mean "jerk". He spreads the word and it becomes fashionable among his schoolmates, providing him with desired, though ephemeral, popularity: "Cork-nut, he'd say to anyone who pissed him off (...). No one but him and Alex the parrot knew exactly what cork-nut meant, so it was pretty demolishing. It became a fad, among the kids at the HelthWyzer Compound, so Jimmy was considered medium-cool" (OC: 67).

Jimmy's obsession with words continues when he becomes an adult. As Snowman, whole passages from old books and lists of obsolete words learnt by heart come to his mind from time to time. Most often, the passages are simply remnants of the past, and therefore useless to him in his new reality. They are fine-sounding sentences, but meaningless, pretentious and out of place:

Each one of us must tread the path laid out before him, or her, says the voice in his head, a man's this time (...), and each path is unique (...). 'Stuff it,' says Snowman. Some cheap do-ityourself enlightenment handbook, Nirvana for halfwits (OC: 23). 
The human body is ninety-eight per cent water, says the book in his head. This time it's a man's voice, an encyclopedia voice (...). The other two per cent is made up of mineral, most importantly the iron in the blood and the calcium of which the skeletal frame and the teeth are comprised. 'Who gives a rat's ass?' says Snowman. He doesn't care about the iron in his blood or the calcium in his skeletal frame (OC: 109).

As regards the lists of words, sometimes they have a soothing effect (like Oranges and Lemons, the song in Nineteen Eighty-Four which connects Winston with a happier past); at other times, however, they are painful because those words are no longer shared and therefore they are useless: words like valance, pibroch, mephitic, doldrums, or maudlin are doomed to oblivion because speakers do not need them any more:

Sometimes he'd turn off the sound, whisper word to himself. Succulent. Morphology. Purblind. Quarto. Frass. It had a calming effect (OC: 344).

But there was no longer any comfort in the words. It no longer delighted Jimmy to possess those small collections of letters that other people had forgotten about. It was like having his own baby teeth in a box (OC: 261).

It should be noted that most of these words are too formal or sophisticated to be useful to the group in power. As happens in Nineteen Eighty-Four, the privileged group is trying to control behaviour by narrowing thought, and the simplification of vocabulary in both form (respelling) and meaning contributes to this process of mental restraint.

In contrast with Crake, a number person who, from his position of power, has the ability to create realities in and out of discourse and manipulate the rules of life, Jimmy is just a word person. Words are his realm, and he can only manipulate the rules of language. Therefore, he enjoys the power of connecting words and meanings at will. For example, when he is alone with the Crakers and has to answer all their questions about a world they do not know, he reflects upon the word toast, with which the Crakers are not familiar, and upon all the different meanings he could attach to it if he wanted to:

'Please, oh Snowman, what is toast?' (...) 'Toast,' he says, 'is something very, very bad (...)'. Toast is when you take a piece of bread (...). Toast was an implement of torture (...). Toast was a ritual item devoured by fetishists (...). Toast is me. I am toast (OC: 97-98).

Toast can mean anything or nothing at all, and he has the power to make it happen, but only in the Crakers' microcosm. Jimmy becomes aware that his discourse cannot actually change reality outside that microcosm because he does not belong to the group in power. That is a feasible reason why, at the end of the novel, he might decide to stay with the Crakers, where he is someone, instead of returning to the world of humans, where he is no one.

Jimmy's motivation for lexical creativity can be traced back to his inferiority complex. $\mathrm{He}$ is actually nullified by practically all the characters in the novel: his parents are both 
eminent scientists, his best friend Crake has a dominant personality and a scientific mind which Jimmy envies and admires, and even Oryx, a girl with an obscure past who becomes Jimmy's obsession, is able to nullify him through sex. He wants to feel valued and resorts to his mastery over words before Crake, before his mates, and even before the Crakers, for whom he is a guide and an interpreter. He does so because he needs appreciation and manipulating words, useless as it is in a world where he has no power, is the only thing he's really good at.

\section{Conclusion}

Atwood's return to speculative fiction is a disturbing picture of a hopeless near future. Among other topics open to debate, the novel brings together the best and the worst face of progress and globalization. The reader witnesses death travelling at the same speed as information, whereas scientific progress, which apparently intends to make human life easier, turns out to be the disguise of consumerism, which is just another form of slavery. Discourse is ultimately found to serve the interests of a privileged minority, who uses it to maintain their position of power and to produce knowledge which is blindly accepted as absolute truth.

From a linguistic perspective, Oryx and Crake offers a reasonable insight into what the English language might be like in the near future as regards word formation. Language is a living instrument, so it evolves with its users and adjusts to the times; accordingly, some words fall out of use because speakers no longer have need for them, whereas some new words arise in response to different motivations: pragmatic, communicative and connotative. Both the birth and the death of words are duly illustrated in the novel, and only those words which can help the group in power to achieve their aims are entitled to survive. In Nineteen Eighty-Four the reader witnesses a similar process of manipulation when Newspeak is devised to replace Oldspeak.

This article shows how language resorts to the productive use of already existing devices to cater for both new and ever-present needs. Therefore derivation, shortening, compounding, blending and respelling are used to name new realities, to speed up communication, to gain in conciseness, to awaken positive associations, to build individual and collective identities, and above all, to maintain a desirable status quo.

Both Nineteen Eighty-Four and Oryx and Crake put into practice Foucault's ideas about the manipulative power of discourse, and both present gloomy visions of a future where the individual is nullified and discourse arises as a mechanism to exert absolute control. However, Nineteen Eighty-Four takes Foucault's theories to unfeasible extremes: a totalitarian system with a well-defined political minority in power has been fully introduced, and Newspeak, a new language (or a new discourse) is being developed with the aim of exerting complete control over reality and thought. Newspeak is created with that aim and there is nothing real outside it. If the group in power says "two and two are five", it becomes a firm belief and an absolute truth. By contrast, Oryx and Crake portraits a 
future which is somehow more distressing because it reaches reasonable extremes. Power is not only exerted by means of discourse; on the contrary, new realities, which are feasible in the light of the present development of science, are also created, and they contribute, together with discourse, to the perpetuation of the system.

\section{Notes}

1. The dates provided here are those of the original works. However, having been taken from translations, the quotations from those works will be followed by the dates of the translations.

2. From here onwards, quotations from the novel will be followed by the abbreviation $O C$ (Oryx and Crake) and the page number.

3. In all the quotations the words in italics are also italicized in the original.

\section{Works Cited}

Algeo, John (ed.) (1991): Fifty Years among the New Words. Cambridge: Cambridge University Press.

Atwood, Margaret (2003): Oryx and Crake. London: Bloomsbury.

Bauer, Laurie (1983): English Word Formation. Cambridge: Cambridge University Press. . (2004): A Glossary of Morphology. Edinburgh: Edinburgh University Press.

Foucault, Michel (1966): Les motes et les choses, une archéologie des sciences humanes. Trans.

Elsa Cecilia Frost (1968): Las palabras y las cosas, una arqueología de las ciencias humanas. Mexico: Siglo XXI Editores.

. (1975): Surveiller et punir. Naissance de la prison. Trans. Alan M. Sheridan-Smith

(1995): Discipline and Punish: The Birth of the Prison. New York: Vintage Books. . (1976): Histoire de la sexualité, Vol. 1: La volonté de savoir. Trans. Robert Hurley (1978): The History of Sexuality, Vol 1: The Will to Know. New York: Pantheon Books. . (1980): Power/Knowledge: Selected Interviews and Other Writings 1972-1977. Ed. Colin Gordon. Harlow: Pearson Education Ltd.

Orwell, George (1989/1949). Nineteen Eighty-Four. Harmondsworth: Penguin.

Pyles, Thomas and John Algeo (1982): The Origins and Development of the English Language.

New York: Harcourt Brace Jovanovich Publishers. 